\title{
6 Fashioning Death: Clothing, Memory and Identity in 16th Century Swedish Funerary Practice
}

\section{Introduction}

King Gustav Vasa was married three times. In 1531, less than a decade after his election as King of Sweden, he made a match calculated to boost his prestige and help consolidate his position as king and married Katarina von Sax-Lauenburg, the daughter of Duke Magnus and a relative of the emperor. She bore the king one son, Erik, and died suddenly in 1535 (Svalenius, 1992). After her death, the king married the daughter of one of the most powerful noble houses in Sweden, Margareta Eriksdotter Leijonhufvud in 1536. Queen Margareta bore the king eight children before she died in 1551. By August of 1552, the fifty-six year old Gustav Vasa had found a new queen, the 16-year-old Katarina Gustavsdotter Stenbock, daughter of another of Sweden's leading noble houses. Despite the youth of his bride, the marriage bore no children and the old king died eight years later (Svalenius, 1992). The king's death occasioned a funeral of unprecedented magnificence that was unique both in its scale and in its promotion of the Vasa dynasty's image and interests. Unique to Vasa's funeral was the literal incorporation of the bodies of his two deceased wives in the ceremony. They shared his bed-like hearse on the long road to Uppsala and the single copper casket that was interred in the cathedral crypt.

Six months after the funeral, Gustav Vasa's son with Katarina von Sax-Lauenburg, Erik, was crowned king. Surprisingly, in one of his first official acts as king, Erik XIV commissioned an official history, or Relation, of his father's elaborate funeral. The importance of the inclusion of Gustav Vasa's queens is evidenced by the fact that the author of the Relation did not simply note the presence of the queens' bodies; he provided a detailed description of the preparation of the body of queen Katarina for the funeral. The significance of this aspect of the funeral is further evidenced by its privileged location in the Relation's second paragraph and by its presentation in scholarly Latin, in contrast to the Swedish used for the majority of the Relation. The section reads:

Clauditur hoc in Sarcophago diua Katharina inuictissimi Suecorum Gothorum ac Vandalorum Regis diui Gostaui prima vxor, Et Erici mater, quæ carnis humanæ viam ingress 1535 Cum Holmiæ in fano diui Nicolai 25 annos reposita fuiset in sacrario, a Joanne duce Finlandiæ diui Gostaui ex diui Margareta secunda vxor fillio, nouis vestibus sceptro et corona redimita, in hocque nouo sarcophago 
reposita, ex mariti cum adhuc viuerat et filij tunc regnatis, vna cum diuo Gostauo Rege marito suo Vpsaliam translate fuit, Anno et die supra prænotato etc. (Olson, 1956, p. 66-67) ${ }^{1}$

Translated this reads as (some punctuation added):

Enclosed within this sarcophagus [is] blessed (deceased) Katarina the first wife of blessed (deceased) Gustav the invincible king of the Swedes, Goths, and Vandals, and mother to Eric. Her mortal flesh was interred in 1535 in Stockholm in the Temple of Saint Nicholas [Storkyrkan] and reposed for 25 years in the sacristy. Johan, duke of Finland, son of the blessed Gustav and blessed Margareta, his second wife, clothed her [Katerina] anew and restored [her] sceptre and crown and placed her in this new sarcophagus. Her son [Erik] by her husband [Gustav] yet lives and rules this kingdom. Together with her husband, the blessed Gustav, she was translated to Uppsala in the year and day noted above ...

Why did Johan disturb a long-dead corpse and provide it with a new dress? Why did Erik include the preparation of his mother's body for reburial among those things that he wished to be remembered by future generations? What purpose could this memory possibly serve?

In 1943, the graves of the early Vasas were opened and subjected to a thorough scientific investigation as part of the ongoing restoration of Uppsala Cathedral (Olsson, 1956). When the coffins of Gustav Vasa and his two queens, Katarina SaxLauenburg and Margareta Leijonhufvud were opened, it was discovered that the bodies of both queens, not just Katerina, had been subject to repeated dressing and re-dressing prior to their final interment at Gustav Vasa's side in 1560 (Olsson, 1956). The fate of the queen's bodies, their interment, repeated disinterment, clothing, and re-clothing in the decades before they finally found rest at the side of Gustav Vasa is an odd but significant chapter in the history of the early Vasa monarchy. It reflects both the transformation in ritual and doctrine that accompanied the Reformation of the Swedish church and the growing ambitions of the Vasa dynasty. I would also argue that the fate of these women's bodies demonstrates the Vasa princes' awareness of the power of history - of memory - to give meaning to the present and to shape the future. Their treatment of the queens' bodies was a literal re-membering or reconstruction of history that did not differ dramatically from the historical manipulation common to the literary products of the royal chancellery or the public ritual demonstrations of the coronation and the royal funeral. The repeated re-clothing of the queens' bodies involved the literal reconstitution and reassignment of meaning and identity and this

1 This account exists in various manuscript copies that exhibit slight variations though they contain essentially the same material. The so-called Linköping Manuscript is thought to be closest to the original document commissioned by Erik XIV. It contains a lengthy Latin introduction announcing the king's death and the great solemnities that were celebrated to commemorate his passing and remarks on the inclusion of his two defunct wives in the ritual. It then proceeds directly to a description in Latin of the renovation of the queens' coffins and bodies previous to the funeral. It does not include as much genealogical material as other versions, such as Peringsköld. 
process facilitated the creation of very specific types of memory. However, because the re-clothed bodies were never intended for public display, we can assume that this memory was private - or intended for a very limited audience. Ultimately, I would argue, the fashioning of the queens' corpses reveals a part of the process by which the Vasa princes fashioned their public and private selves (Greenblatt, 2005).

Historians since Kantorowicz and Giesey have explored the ways in which the royal mortuary practices related to both the representation of power relationships and to shifting understandings of the human body (Bertelli, 2001; Giesey, 1960; Kantorowicz, 1957; Strocchia, 1992; Woodward, 1997). The overwhelming preponderance of this literature has focused on the bodies of kings and male members of the political elite. This paper contributes to this discourse, but extends the focus of study to feminine bodies, and to queens specifically, and thereby participates in recent scholarship on women and power (Gold, 1985; Grönhammar, 1999; Poutrin \& Schaub, 2007; Stafford, 1983). The fashioning and refashioning of the women's bodies to create specific types of memory brings that set of practices within the ambit of work on renaissance 'selffashioning' (Greenblatt, 2005), self-representation (Crane, 2002; Hayward, 2007; Jones \& Stallybrass, 2000; Rubin, 2007) and historiography (Johannesson, 1969-1970, 1991).

Traditional document-based historical method faces limits when brought to bear on questions concerning feminine bodies and royal power, the process of selffashioning or the generation of representations of royal power in the 16th century. In many cases documentation is scarce or nonexistent, and where it exists it frequently provides a limited perspective. The tombs of the early Vasa princes are a rich source of material evidence that shed light on these elusive elements of Swedish history. Gustav Vasa's seminal role in the development of the Swedish state ensured his tomb's preservation to the present and, though the funerary chapel itself has been subject to considerable remodelling, the tomb monument executed 1562-1583 and the graves themselves have been well protected and preserved (Sjöholm, 1982). A thorough scientific examination of the tomb, crypt, and royal remains was carried out in 1945-1946 by a team of researchers including archeologists, historians, art historians, anatomists, radiologists and historians. The remains of Gustav Vasa, his three wives Katarina von Sax-Lauenburg, Margareta Leijonhufvud and Katarina Stenbock, his son and successor Johan II, and his second wife Gunilla Bielke were exhumed together with their funerary paraphernalia. The remains were subject to a thorough examination and conservation before being returned to their original places in the crypt where they remain to the current day (Olsson, 1956).

Gustav Vasa selected Uppsala cathedral to be the necropolis for the kings of Sweden based on a number of factors. The cathedral was the seat of Sweden's preeminent ecclesiastical authority and it had associations with the mythic Gothic kings and with the sainted king Erik Jedvardsson (d. 1160). But for a variety of reasons his son Johan III and his two wives, Katerina Jagellonica and Gunilla Bielke, were the only other members of the Vasa dynasty to be buried in the cathedral. Nevertheless, 
Gustav Vasa's funeral ritual and his interment in a crypt, was widely imitated by his successors and by the high nobility. The use of crypts protected the remains and facilitated periodic examination of the tombs and their contents by clerics, high status visitors, and researchers. Though Queen Katerina Jagollonica's remains have not (to my knowledge) been subject to close scientific study, her grave goods, including her personal jewellery and funerary regalia, have been removed from her tomb and are on display in the Uppsala cathedral treasury (Sjöholm, 1982).

The overwhelming majority of medieval Swedish kings and queens elected for interment in their preferred monastic institutions and, with a few exceptions, the precise location of their graves has been lost for centuries. In some cases the reputations of the kings or political considerations helped to keep the memory of their burial place alive; for instance the graves of King Magnus Ladulås (d. 1290) and Karl Knutsson Bonde (d. 1470) that are located in the former Franciscan convent church in Stockholm known today as Riddarholm's church (Riddarholmskyrkan). Their graves were excavated and subject to extensive study starting in 1915 (Fürst \& Olsson, 1921). The graves of Sweden's early modern rulers, Erik XIV, Gustav II Adolf, Karl X Gustav, Karl XI, Karl XII, and Gustav III have all been opened and subject to varying degrees of scrutiny most frequently in connection with church restoration projects (Casparsson et al., 1962; Curman \& Roosval, 1937; Janson, 2004). Of these, Erik XIV and Karl XII have been subject to the closest study. In both of these cases the primary interest has been in determining who or what killed the king. Otherwise, the tombs have been the subject of art historical description, conservation and restoration. This paper is a departure from the majority of previous work on Sweden's royal tombs in that the focus is on recovering aspects on the cultural and intellectual world of the late 16th century particularly with regard to the construction of royal power and understandings of the female body.

\subsection{Remembering the King}

Gustav Vasa was born into one of the most powerful of clans that dominated Swedish politics under the Danish-led Kalmar Union. In the wake of the Stockholm Bloodbath, he assumed leadership of Swedish forces fighting for independence from the Danish crown, defeating the Danish King Christian II in 1523. Shortly after his victory, he was elected King of Sweden (Svalenius, 1992). As monarch, Gustav Vasa laboured tirelessly to unify the Kingdom and to provide it with a government and an identity capable of withstanding internal divisions and external threats. In the process, he made a number of radical breaks with Swedish tradition; most significantly, he broke with the religious leadership of Rome and transformed the monarchy from an elective to a hereditary form (Behre \& Österberg, 1994). These changes ultimately transformed Sweden from a province to a state, laying the foundations for future political, economic and cultural developments, but at the time they became a source of gnawing insecurity. The king was well aware that he was viewed as a noble upstart and that 
the Danish king and his allies watched his every move. Consequently, when Gustav Vasa died in the early morning hours of September 29, 1560, both his subjects and his heirs received the news of his passing with sorrow and considerable trepidation (Ordinarius, 1905). His death placed the new political and religious order in jeopardy and fueled fears that the fledgling state would descend into the chaos of civil war or to the horrors of foreign invasion. However, at the same time, his death presented a potent opportunity for the young Vasa dynasty to further its own political agenda by presenting a carefully crafted recasting of the life and deeds of the dead king that would buttress their own claims and ambitions.

Erik could best achieve that reframing of his father's legacy in the royal funeral ceremony, a quintessential occasion for memory. The deceased may be eulogized, his or her memory elaborated and codified, and by this process the funeral's participants can ratify an official account or story of the deceased. The ritual context provided a particularly powerful opportunity to shape the history of Gustav Vasa because the formalized, distinctly non-quotidian sequence of actions enabled the performers' ability to represent and thereby actualize an intangible ideal, or in this case, a memory (Geertz, 1973). Erik's awareness of the power of memory - of history - are reflected in the opening sentences of the Relation, that begins with an invocation that states:

Thetta efterscreffna och till minnes antechnat for effterkommandenar skull ... (Linköpings Stadsbiblioteck MS T131 F.1., n.d.; Peringsköld, 1791).

(This text is written so that [our] descendants will remember ...)

The ruling classes of the Renaissance had a keen appreciation of the power of memory - of history - to shape the world they lived in. When the Swedish clergyman Olaus Petri began his Swedish Chronicle sometime in the 1530s, he did so with a passage that highlighted this awareness:

Gudh som all ting haffuer skapat menniskione til godho och gagn, han haffuer the tock aff sinne ewiga godheet och försyyn så förordinerat och skickat, at theres liffuerne och regemente som fordom dags $i$ werldenne leffuat haffua bescriffuas skulle, theres epterkommandom til en rettilse och warnagel, aff huilkom the lära motte ... (Petri, 1917, p. 1)

(God who has fashioned all things for the good and benefit of his people, has of his eternal goodness and foresight so ordained that the lives of men and their deeds of days gone by should be written down as an example and warning from which they may learn ...)

Petri's view is typical of his age. He perceives history as a kind of useful remembering and, as he elucidates in later pages, an overtly political act. The Vasa princes unquestionably shared his understanding of the power of history. From the earliest years of Gustav Vasa's reign, his Chancellery produced propaganda in Swedish, German, and Latin in the form of open letters, broadsheets, songs ['visor'] and 
scholarly polemic in Swedish, German and Latin; all based on the artful re-telling of recent events and history (Johannesson, 1969-1970).

In the case of Gustav Vasa's funeral as recalled in the Relation, precisely what Erik wished to be remembered, and by whom, is a surprisingly complicated issue. He wanted different individuals and groups to remember different things, and this becomes evident in his account. On one hand, Erik clearly intended to memorialise the magnificence of the ritual that honoured his father (and his memory). However, Erik's notation of the particular families in attendance documented their loyalty and the support they had given the king, his father, in life and bound them to his memory. Erik thereby established a precedent for the nobility's participation in the Vasa regime by fixing another memory, that of their participation in the ritual expression of the regime as elaborated in the funeral ritual. In other words the funeral account was intended to fix the memory not only of the funeral, but also of bonds of fealty and allegiance.

Not surprisingly, Gustav Vasa's funeral was the most elaborate that had ever been staged for a Swedish monarch (Gonzalez, 1999; Usthall, n.d.). It was carefully crafted as a response to the contemporaneous conditions in Sweden, and as a remedy for the general atmosphere of fear and uncertainty at the time of his death. The king's body lay in state for eight long weeks, during which frenzied preparation took place for the two-day-long procession that would transport the bodies to Uppsala cathedral for burial. Lifelike effigies of Gustav Vasa and his two defunct queens were commissioned from the leading artists in Sweden together with heraldic devices, a castrum doloris and lavish hangings to transform the royal palace and the cathedral into suitable expressions of mourning and royal glory. When all of the parts were assembled in the context of the royal funeral, the totality constituted a discourse centred on four main ideas: the unity of the Swedish realm, the victory of the Reformed Church, the legitimacy of the Vasa dynasty and the hereditary monarchy, and Sweden's full and equal participation in European culture and politics. The ritual was a communal act of remembrance that was intended to cast Gustav Vasa's history as a powerful exemplum of royal power that aimed at shaping the past and the future.

Erik XIV's appreciation of the power of history and ritual derived from a solidly humanist education. His father, concerned that his sons be true princes, recruited the Wittenberg-trained humanist George Norman to serve as their tutor (Andersson, 1993; Hoffordenung, 1539/1890). Though Norman's attentions were shortly consumed by matters of church and state, he did complete a programme for the prince's education that was designed specifically to shape the heirs of the nobleman, Gustav Vasa, into ideal princes. Latin and the catechism formed the core of the princes' daily lessons; but their course of study also included texts that were considered relevant to their moral and vocational development: Aesop's fables, passages from scripture - the wisdom of Solomon in particular - and selected classical texts and histories that exemplified virtue or that were recognized for their intellectual value (Hoffordenung, 1539/1890). The study of history was particularly prominent as is evidenced by the 
long list of classical and contemporary works of history listed among the purchases made for the princes' court. According to the humanists, history was essential to the education of princes because it provided exempla, or models, for behavior. History, in other words, was not simply the repetition of the tales of old kings and heroic deeds; rather, it required both internalising the lessons and morality extracted from the tales and enacting them in appropriate situations. In Norman's writings, this point is made explicitly. Borrowing from ideas expressed in Cicero's On Obligation, the royal tutor strove to instill eloquentia corporis (Cicero, trans. 2000; Johannesson, 1980). The princes were taught not just to think like princes, but also to act like princes; and acting like a prince literally meant that they were encouraged to model the examples of princely virtue found in their books (Hoffordenung, 1539/1890; Johannesson, 1980). The lessons that the princes learned intellectually were expressed physically, acted out in endless repetition in the rituals of the court. For Erik XIV and his brothers, the training that they received as children had particular relevance to the design and execution of the funeral of their father, the king.

\subsection{Brides for a King}

Within a year of his coronation as king of Sweden, Gustav Vasa began his search for a bride that would bolster his reputation, foster political connections and allegiances, and provide him with heirs. Following lengthy negotiations, Katarina von SaxLauenburg, the daughter of a princely house with ties to the Holy Roman Emperor arrived in Sweden in 1531 and married Gustav Vasa on her 18th birthday. Two years later, the queen gave birth to a son, Prince Erik. Then, writes Peder Svart (1870: 174), af hwilken önskelige födelse heela rijkit blef vpfylt med frögd och glädje, och Konung Gustafz regemente blef ther igenom mykit styrkt och stadfest ... (of this longed for birth the whole realm was filled with rejoicing and happiness and King Gustav's government [rule] was much strengthened and secured...)

Though documentary evidence of Katarina's years in Sweden is sparse, tradition has long held that the marriage was unhappy. The queen died in 1535 amid rumors that the king had beaten her to death (Svalenius, 1992). Contemporary Swedish sources mention Katarina's death only in passing and provide no real details concerning her funeral or burial. The chronicler Erik Tegel recorded that she was buried in Storkyrkan and a long-vanished document published by the antiquarian Peringskiöld in the 18th century indicates that her grave was located in the choir north of the altar (Larsson, 2002; Olsson, 1956). Gustav Vasa remarried within a year of Katarina's death. This time, his bride was Margareta Eriksdotter Leijonhufvud, the daughter of one of the most powerful noble families in Sweden. Tradition holds that this marriage was extremely happy - though there is no real evidence to support this view. It was, regardless, certainly very fruitful. Within a year of their wedding, Margareta gave birth to a son, Johan, and went on to produce nine more children in 
the years before her death in 1551 (Larsson, 2002). The intervening years were busy in other ways as well. The Reformation of the Swedish Church, begun at Västerås in 1527, had overcome any initial resistance and Lutheran theology and ritual forms had come to dominate Swedish religious life (Andrén, 1999; Grell, 1995). Vasa had emerged victorious from the various challenges to his rule posed by the Danes and his rebellious subjects - most seriously, the insurrection led by Nils Dacke in 1542 (Larsson, 2002). With the consolidation of his power accomplished, Vasa moved to secure the elective throne of Sweden for his heirs forever, and at the Riksdag of Västerås in 1544, the Swedish estates vowed to recognize Gustav Vasa's sons as their hereditary kings (Larsson, 2002). Yet despite all of his domestic achievement, Gustav Vasa and his sons were acutely aware that the majority of the ruling houses of Europe still viewed them as 'noble upstarts' and encouraged them in their efforts to achieve recognition by acting like kings, looking like kings, and developing scholarly proofs of their dynastic worthiness.

When Queen Margareta failed to recover from the birth of her youngest child and died in 1551, the ritual response to her passing was dramatically different from that provided for Queen Katerina. Queen Margareta died in the castle of the Bishop of Strängnäs. The king's initial plan was to bury her in the local cathedral, and he immediately issued orders for the preparation of a grave. However, two days later, he countermanded those orders and sent a letter to his son Erik, saying:

K. M:tt achter late begraffve vår alder nådigeste fru I Stockholm, at than förthenskuld later uptage drottning Katerina och sättie henne in I sakerstijgen...(Olsson, 1956, pp. 69-70)

([His] Royal Majesty commands that our most gracious lady wife be buried in Stockholm, and that for this reason he [Erik] should disinter queen Katerina and place her in the sacristy [of Storkyrkan].)

Funerals seem suddenly to have been very much on the king's mind. An undated letter from Erik to his father in 1551 indicates that the king had decided to be buried in Uppsala, that a burial crypt in the chapel behind the choir was in preparation, and that stone sarcophagi had been commissioned to contain the remains of his two queens (Gillgren, 2009; Olsson, 1956). This represents a clear shift from earlier practice and reflects the recently elevated status of the Vasa dynasty to hereditary princes. A hereditary house required a pedigree. What better way to manifest the Vasa bloodline than in monuments made of stone? Similarly, the ritual that accompanied Queen Margareta was far more elaborate than that provided for her predecessor. A flurry of correspondence between Erik and his father indicates that the funeral was the subject of meticulous planning that was undertaken with the help of the Wittenbergtrained humanist George Norman. Yet despite the elaborate funeral, the queen was not buried. Her body, dressed in a plain gown of black velvet and bearing a crown and sceptre of gilt wax, would lie in the sacristy of Storkyrkan for nearly a decade before she would come to her final resting place (Olsson, 1956). In the meantime, Prince Erik 
obeyed his father's command and disinterred the body of his mother from the place where it had rested for sixteen years beside the choir in Stockholm's cathedral. In an undated letter from 1551 he writes:

I dag, när kisten, ther min kiäre fru moderss salig ihukommelse affsompnede lechame udi lagd var, up aff graffven tagin bleff, befantz, att kisten och vaxduken våre så förrothne, att hon ecke flyties eller föres kunde, dherföre bliffver nu en ny kiste giordh, ther then gamble innen i sättias skall, oc sedan bliffve bedragen umkring med nye vaxduker.... (Olsson, 1956, p. 65)

(Today when the coffin containing my dear lady mother of blessed memory's dead [affsompnede] body was uncovered and taken up out of the grave it was found that the coffin and waxed cloth [oil cloth] was so rotten that she could not be moved. Therefore shall a new coffin be made to contain the old one and then covered in new wax cloth...)

Erik then requested that his father send supplies and cloth-of-gold for the bier and to cover the coffin. When Queen Katarina was installed in her new coffin she joined Queen Margareta in the sacristy where she would wait for nine years before finally going to her final resting place in the crypt of Uppsala cathedral. ${ }^{2}$ Indeed, when the grave was opened in 1943, the truly extraordinary nature of Erik's impact on his mother's remains was brought to light. Erik's was the first of two interventions undertaken to repair the body previous to the funeral of Gustav Vasa in 1560. When her coffin was opened, the queen's body was found within the 'new' coffin dressed in two layers of clothing. The outermost layer was the gown in which the queen was dressed in 1560. Under this dress was a second gown of black velvet. Importantly, the body was not wearing the gown. The garment had been made in such a way that it might be tucked in around the corpse and thus present the illusion that the body was dressed. When the grave was examined, there was no evidence of earlier clothing (Olsson, 1956). This is interesting because in contemporary practice (e.g. Queen Margareta) corpses were routinely dressed after death. However, in this case the queen's garment seems to have been applied after the body had decomposed. This thesis is strengthened by the fact that part of the body's right arm was displaced and lay under the pillow that supported the queen's head (Olsson, 1956). But if this dress was placed on the body when Erik restored the coffin, where is the original dress?

In medieval Sweden, it was customary to bury the deceased naked, wrapped in a shroud (Fürst \& Olsson, 1921; Troels-Lund, 1984). Queen Katarina died only a few short years after the beginning of the Reformation and before new theological understandings of the afterlife of the body took hold. During the Catholic period, the doctrine of purgatory seemed to suggest that divine judgment took place immediately

2 It should be noted that this translation of human remains would have been extremely unusual in a Swedish context. Though there is evidence that noble families in some circumstances moved grave monuments from defunct churches to active churches during the Reformation (Hamner, 1933), I know of no instance where the remains of any other lay person were treated in a similar manner. 
after death (Reinis, 2007; Troels-Lund, 1984). Given this view, it is not surprising that the corpse held little importance and most were evidently consigned to their eternal rest wearing a simple shroud of oilcloth (Magnus, 2001; Olsson, 1956). However, with the advent of Lutheranism, beliefs and customs changed. With the elimination of purgatory, the fate of souls awaiting the last judgment had to be re-evaluated. Ultimately, Martin Luther decided that the souls of the deceased slept while awaiting resurrection on the last day (Altjaus, 1963). The impact of these ideas on Swedish perceptions of death is indicated by the increased use of the term avsomna to indicate death. But if the dead were just sleeping, then a new treatment of the dead body was also mandated. It is very probable that queen Katarina was originally buried according to the medieval custom, in a simple shroud. The shift in religious doctrine and concurrent evolution of the view of dead bodies is mirrored in Erik's attention to his mother's body; according to Olsson (1956), he supplied her with both a dress and a pillow!

However, beyond the theological significance of Erik's actions, the dressing of the queen's body also has wider implications in terms of understandings of the body and the construction of memory (Crane, 2002; Hayword, 2007; Jones \& Stallybrass, 2000; Rubin, 2007). The velvet dress that was tucked around her remains was a garment fit for a queen and its bestowal endowed a desiccated corpse with significance, a social status, and an identity. Mouldering remains became a queen, and Erik, who can hardly have remembered his mother alive, constructed a proof of his royal origins. Just how far Erik and his brother Johan were willing to pursue this process became fully apparent nine years later with the death of their father, Gustav Vasa, on September 29,1560 . While the court engaged in frenzied preparations for the king's funeral, Erik commanded that his mother's coffin be opened once more and the body refurbished in preparation for its final burial. Though the official account commissioned by Erik only mentions the body of Queen Katarina, when the graves were opened in 1943, it became apparent that the body of Queen Margareta had also been subject to considerable attention. During the preparations for Vasa's funeral in 1560, Queen Katarina was provided with a new dress that was constructed in a like manner to the garment in which she was dressed in 1551 (i.e., it consisted only of a front piece that was tucked around the body to give the appearance of clothing); but this dress was considerably more elaborate and far more costly. The dress was made of Lucca velvet, the highest possible quality available at that time, and in a design consistent with contemporary European court fashion. Whereas the earlier dress was unadorned, this dress was trimmed with a three-centimeter broad gold ribbon around the neck, around the arms, and along the hem. Three crowned silver-gilt initials, K[aterina], $\mathrm{R}$ [egina], S[uecia] were stitched to the breast and each of the crowns was set with three pearls (Olsson, 1956). If this dress left any doubt as to the regal nature of its bearer those doubts would have at once been dispelled by the silver-gilt crown that was placed on the queen's head over a cap made of cloth of gold. The queen's body was also provided with a sceptre that had a handle set with pearls (Olsson, 1956). 
Interestingly, the crown that was placed on Katarina's head was different from any that she had worn in life. The medieval Swedish kings wore open crowns and Gustav Vasa seems to have followed this tradition (Cedarström, 1942). But this crown was of the closed, or imperial, type that was growing in popularity throughout Europe (Olsson, 1956). It was a symbolic claim of equality with the other older and more established royal houses of Europe, which is all the more striking because of its novelty. It is also interesting that while the notoriously parsimonious Gustav Vasa had furnished his second wife with symbolic regalia made of wax, Erik invested in the real thing. The new regalia were made of silver and gold and set with pearls. Yet these objects of considerable material value were intended for a very limited audience. Only the individuals directly involved in the process of refurbishing the queen's bodies would have seen the queen's finery or her new regalia.

Prince Johan also refurbished the coffin of his mother, Queen Margareta, though whether he did so at Erik's command is unclear. Like Queen Katarina, Margareta was provided with a new dress that was a mere front piece that could be tucked over the original dress that contained the body of the queen. This dress was made of black velvet of a common quality that was also used to upholster the coffins and to make various drapes and hangings (notably for the horses) that were used in the funeral ritual. The queen's dress was of slightly different design than Katarina's; it had puffy sleeves trimmed with $23 \mathrm{~mm}$ of broad gold ribbon that provided an elegant touch, but that was markedly narrower then the ribbon that decorated Queen Katarina's gown. The same ribbon trimmed the hem (Olsson, 1956). Three silver-gilt crowned initials were sewn to the bodice, M[argareta], R[egina], S[uecia], but in contrast to those that ornamented Queen Katarina, the crowns were not set with pearls. When Margareta died in 1551, she was provided a crown and sceptre of gilt wax. These had decayed in the years since her death and were now replaced with a silver-gilt crown of the closed type and a sceptre of design similar to those given Queen Katarina, but without the inset pearls (Olsson, 1956).

The people of the Renaissance were well-accustomed to reading clothing, and the humanist-trained Vasa princes had been educated since birth in the rhetorical process by which meaning is created (Barthes, 1985; Johannesson, 1980). The differences in the queens' ensembles are subtle but obvious, and were very clearly intentional. Everything from the quality of the fabric to the details of decoration serves to distinguish the women in very specific ways. Queen Katarina's dress was made of better quality fabric and was trimmed with broader gold ribbon than that of Margareta, whose jewellery and sceptre is of simpler design and lacks the pearls that decorate Katarina's regalia. The message is clear: Katarina was the daughter of a princely family; Margareta was only ‘common' nobility. Even more interesting is the fact that Katarina's sceptre has ornamentation identical to that borne by the king, and the velvet used for her dress was also used to make Gustav Vasa's burial robe and the suit of clothes worn by Prince Erik when he followed his parents' coffins to their final resting place (Olsson, 1956). In other words, Erik was not content simply to distinguish 
his mother's lofty pedigree: he was clearly highlighting his royal birth through the construction of a material connection between himself and his parents. At a moment of tremendous dynastic insecurity, when the principle of hereditary monarchy was as yet untested, Erik moved to reinforce his claim to the throne by creating a material link between himself and his royal parents: he was literally cut from the same cloth.

But who was this message for? The crowds that viewed the funeral procession would have remarked the quality of the velvet worn by the prince, but they could not have known that it matched the outfits worn by his parents in their coffins. Though Gustav's body lay in state for eight weeks, the queens' bodies were badly decomposed and there was clearly never any intention of displaying them. The individuals who would have known what dresses the queens wore cannot have been many. Yet it is clear from the account Erik commissioned of his father's funeral that this specific fact was one of the things that he wanted to be remembered. Why? The text offers us several clues. First, unlike most of the account, the section that reports the restoration of Queen Katarina's coffin is in Latin. This means that it was meant for an educated audience and was not intended for general consumption. Prince Johan is specifically named as the person who was responsible for the preparation of the queen's body for Vasa's funeral and he was arguably among the most learned men in Sweden. He would have been intimately familiar with the process of preparing the bodies - and it cannot have been pleasant!

The intense rivalry between Erik and Johan is well documented. Johan, who through his mother could lay claim to bonds of kinship with many of the most powerful Swedish noble clans, represented a real threat to Erik's claim to the throne. The monarchy had previously been elective and Johan's family ties presented him with a clear advantage, one that he would exploit in 1568 when he overthrew Erik and claimed the throne (Larsson, 2005). Erik was very aware of the threat posed by his brother and it is probable that Prince Erik intended the message of the queens' bodies for his brother, and perhaps for his half siblings and their families.

In De Oratore, Cicero has Crassus argue that ideas 'can be most easily retained in the mind if they are also conveyed to our minds by the mediation of our eyes.' He makes the argument that if an orator creates an image that it will shape a thought, and therefore it has tremendous persuasive power. In fact, he argues, it may even convince the audience of a belief that is opposite to their original opinion (Khoury, 2009). The most convincing of arguments, according to Quintilian (as cited in Khoury, 2009, p. 249), are provided by history:

The advantage derived from the knowledge of historical facts and precedents, with which it is desirable that our orator should be acquainted; for such knowledge will save him from having to acquire all his evidence from his client and will enable him to draw much that is germane to his case from the careful study of antiquity. And such arguments will be all the more effective, since they alone will be above suspicion of prejudice or partiality. 
The dressing of the queens was part of a rhetorical process directed by Erik in which corpses were endowed with identity and meaning. It was a literal re-membering of history in which Johan came face to face with an image - history in its most literal form. The argument, the memory, the precedent, was absolutely clear and irrefutable. The long dead Queen Katarina was of royal blood - Queen Margareta was merely noble. Erik thus had a clear and undeniable right to the crown of Sweden. This was ultimately what Erik wanted to be remembered. He was his father's eldest son, and the only son of royal blood. He and he alone had right to the crown of Sweden as its true hereditary prince. The proof was his body.

\section{References}

Altjaus, P. (1963). The theology of Martin Luther (R. C. Schultz, Trans.). Philadelphia, PA: Fortress Press.

Andersson, I. (1993). Erik XIV. Stockholm, Sweden. Wahlström \& Widstrand (Falun: Scandbook).

Andrén, Å. (1999). Sveriges kyrkohistoria; Reformationstid. Trelleborg, Sweden: Berlings Skogs.

Barthes, R. (1985). The fashion system. London, England: Trinity Press.

Behre, G., Larson, L., \& Österberg, E. (1994). Sveriges Historia 1521-1809: Stormaktsdröm och småstatsrealiteter. Stockholm: Norstedts Trykeri.

Bertelli, S. (2001). The king's body: Sacred rituals of power in medieval and early modern Europe. Philadelphia, PA: The Pennsylvania University Press.

Casparsson, R. et al. (1962). Erik XIV: en historisk, kulturhistorisk och medicinsk-antropologisk undersökning i samband med gravöppningen 1958 i Västerås domkyrka. Stockholm: Norstedt.

Cedarström, R. (1942). De Svenska Riksregalierna och Kungliga Värdighetstecken. Stockholm: Kungliga Livrustkammaren.

Cicero. (2000). On obligation (P. G. Walsh, Trans.). Oxford: Oxford University Press.

Crane, S. (2002). The performance of self: Ritual, clothing, and identity during the Hundred Years War. Philadelphia, PA: University of Pennsylvania Press.

Curman, S. \& Roosval, J. (1937). Riddarholmskyrkan i Stockholm; Konsthistoriskt Inventarium. Sveriges Kyrkor, Stockholm. Bd II. H. 2. Stockholm, Esselte aktiebolag.

Fürst, C. M., \& Olsson, M. (1921). Magnus Ladulås’och Karl Knutssons Gravar i Riddarholmskyrkan. Stockholm: A. B. Teknologföreningens Förlag.

Geertz, C. (1973). The interpretation of cultures. New York: BasicBooks.

Giesey, R. (1960). The royal funeral ceremony in renaissance France. Travaux D'Humanism et Renaissance XXXVII. Genéve, Switzerland: Librairie E. Droz.

Gillgren, P. (2009). Vasarenässansen: Konst och identitet I 1500-talets Sverige. Stockholm: Bokförlaget Sigum.

Gold, P. S. (1985). The lady and the virgin: Image, attitude, and experience in twelfth century France. Chicago, IL: The University of Chicago Press.

Gonzalez, J. (1999). Reality and representation: Myth, ritual, and royal power in Sweden and France 1560-1610 (Doctoral dissertation). Retrieved from UMI (Order No. 9926363).

Greenblatt, S. (2005). Renaissance self-fashioning: From More to Shakespeare. Chicago, IL: University of Chicago Press.

Grell, O. P. (Ed.) (1995). The Scandinavian reformation. Cambridge: Cambridge University Press. Grönhammar, A. (Ed.). (1999). Drottningar: Kvinnlighet och Makt. Stockholm: Livrustkammaren. Hamner, J. W. (1933) Gotlands gravstenar: 1, Visby domkyrkas gravstenar. Stockholm. Hayward, M. (2007). Dress at the court of Henry VIII. Leeds, UK: Maney Publishing. 
Hoffordenung vor die Durchlauchten Hochgeboren Fursten und herrn Erico und herrn Johan gebrudern, der Schweden und Gotthen etc hertzogen, meiner gnedigen herrn Kurtz auf iher gnaden itzig alter gestellet. Undated MS (ca 1539). In Johan Axel Almquist (Ed.), Konung Gustaf I's registratur, Vol. 12, 1538-1539, (pp. 17-34). Stockholm: Riksarkivet, 1890.

Janson, Erik. (2004). Tiden och Döden: kungliga gravöpningar. Stockholm: Wahlström \& Widstrand. Johannesson, K. (1969-1970). Retorik och Propaganda vid det Äldre Vasahovet. Lychnos. Stockholm, Sweden: Almquist \& Wiksells.

Johannesson, K. (1980). Gustav Vasa och renassansen. Stockholm: Aktiebolaget Thule.

Johannesson, K. (1991). The renaissance of the Goths in sixteenth-century Sweden (J. Larson, Trans.). Los Angeles, CA: University of California Press.

Jones, A. \& Stallybrass, P. (2000). Renaissance clothing and the materials of memory. Cambridge: Cambridge University Press.

Kantorowicz, E. H. (1957). The King's two bodies: A study in medieval political theology. Princeton, NJ: Princeton University Press.

Khoury, J. (2009). Machiavelli manufacturing memory: Terrorizing history, historicizing terror. In D. Beecher \& G. Williams (Eds.), Ars Reminiscendi: Mind and memory in renaissance culture (p. 247-266). Toronto, Canada: Centre for Reformation and Renaissance Studies.

Larsson, L. O. (2002). Gustav Vasa, landsfader eller tyrann. Stockholm: Prisma.

Larsson, L. O. (2005). Arvet efter Gustav Vasa: En berättelse om fyra kungar och ett rike. Stockholm: Prisma.

Magnus, O. (2001). Historia om de Nordiska Folken. Viborg, Denmark: Nørhaven.

Olsson, M. (Ed.) (1956). Vasagraven i Uppsala Domkyrka; Historiska, Konst- och kulturhistoriska samt Medicinska och Antropologiska undersökningar (Vol. I-II). Stockholm: Nordisk Rotogravyr.

Ordinarius, J. (1905). Berättelser om k. Gustav I:s sista stunder och död. Historiska Handlingar, 20, 121-157.

Peringsköld, J. (1791). Monumenta Uilerkehensia cum Upsalia Nova. Stockholm: J. L. Horrs.

Petri, O. (1917). En Swenska Cröneka (J. Sahlgren, Ed.). Uppsala, Sweden: Almquist \& Wiksells Boktryckeri.

Poutrin, I. \& Schaub, M.K. (2007) Femmes \& pouvoir politique: Les princesses d'Europe XVe-XVIIIe Siècle. Rennes, France: Oberthur Graphique.

Reinis, A. (2007). Reforming the art of dying: The ars moriendi in the German reformation (15191528). Cornwall, England: MPG Books.

Rubin, P. L. (2007). Images and identity in fifteenth-century Florence. New Haven, CT: Yale University Press.

Sjöholm, Ö. (1982). Uppsala domkyrka: Katedral genom sekler. Uppsala, Sweden: Almqvist \& Wiksell.

Swedish Relation of the funeral of Gustav Vasa. Manuscript in the collection of Linköpings Stadsbiblioteck. (n.d.). MS T131. F. 1.

Stafford, P. (1983). Queens, concubines, and dowagers: The king's wife in the early middle ages. Athens, GA: The University of Georgia Press.

Strocchia, S. (1992). Death and ritual in Renaissance Florence. Baltimore, MD: Johns Hopkins University Press.

Svalenius, I. (1992). Gustav Vasa. Stockholm: Wahlström \& Widstrand (Falun).

Svart, P. (1870). Gustav Is Krönika (G. E. Klemming, Ed.) Stockholm: P.A. Norstedt \& Söner.

Troels-Lund, T. F. (1984). Att dö i Norden: Föreställningar om Livets slut på 1500-talet (T. Nyman, Trans.). Stockholm: Förfatarförlaget.

Usthall [Uphall], L. (n.d.). Unpublished manuscript in the collection of Kungliga Biblioteket, Engströmska samling B. IV.I.5.

Woodward, J. (1997). The theatre of death: The ritual management of royal funerals in Renaissance England, 1570-1625. Woodbridge, UK: The Boydell Press. 